\title{
Germination and fungi incidence in Cerejeira-da-mata seeds at different fruit maturation levels and temperatures
}

\section{Germinação e incidência de fungos em sementes de Cerejeira-da-mata em diferentes estádios de maturação dos frutos e temperaturas}

\author{
Maike Lovatto \\ Universidade Estadual de Maringá \\ E-mail: maikelovatto2@gmail.com \\ OrcID: https://orcid.org/0000-0002-1857-7022 \\ Ediane Roncaglio Baseggio \\ Universidade Tecnológica Federal do Paraná \\ E-mail: ediane bio@hotmail.com \\ OrclD: https://orcid.org/0000-0002-8644-3392
}

Adriana Lugaresi

Universidade do Estado de Santa Catarina

E-mail: adrianalugaresi@yahoo.com.br

OrcID: https://orcid.org/0000-0003-3035-8604

Gian Carlos Girardi Universidade Federal da Fronteira Sul E-mail: gian.carlos.girardi@gmail.com OrcID: https://orcid.org/0000-0003-3031-2323
Alison Uberti
Universidade Federal de Viçosa
E-mail: alisonuberti@hotmail.com
OrcID: https://orcid.org/0000-0002-5372-0533
Clevison Luiz Giacobbo Universidade Federal da Fronteira Sul E-mail: clevison.giacobbo@uffs.edu.br OrcID: https://orcid.org/0000-0002-3023-4831

\begin{abstract}
The effect of different levels of physiological maturation of the fruit and temperature on the seed germination and incidence of fungi that are harmful to the seeds, becomes fundamental for the improvement of the propagation of different native fruit species. The objective of this work was to evaluate the effect of physiological maturation and temperature on the germination and fungi incidence in Eugenia involucrata DC. seeds. Three experiments were carried out. In the experiment I, the effect of four levels of physiological maturation was evaluated, visually determined based on the color of the fruit, and in the experiment II, was evaluated the effect of two levels of maturation and two temperatures $\left(25\right.$ and $35^{\circ} \mathrm{C}$ ) on the germination and vigor of the seeds. In the experiment III, was investigated the incidence of fungi in the seeds at two temperatures $\left(25\right.$ and $\left.35{ }^{\circ} \mathrm{C}\right)$. The levels of maturation evaluated did not influence the percentage of germinated seeds, but they influenced seed vigor. The temperature of $25^{\circ} \mathrm{C}$ was suitable for seed germination. The fungi genera found on the seeds were Trichoderma, Aspergillus, Fusarium, Penicillium, Alternaria, and Colletotrichum with variable incidences depending on evaluated temperature.
\end{abstract}

Keywords: Cerejeira-do-Rio-Grande. Eugenia involucrata. Myrtaceae. Physiological maturation. Wild fruits.

Resumo: O conhecimento dos efeitos de diferentes níveis de maturação fisiológica do fruto e da temperatura sobre a germinação e incidência de fungos prejudiciais às sementes é fundamental para o aprimoramento das técnicas de propagação de diferentes espécies frutíferas nativas. Portanto, o objetivo desse estudo foi avaliar 
a influência do estádio da maturação fisiológica dos frutos e da temperatura sobre a germinação e incidência de fungos em sementes de Eugenia involucrata DC.. Foram conduzidos três experimentos, no primeiro avaliou-se o efeito de quatro estádios de maturação fisiológica distinguidos, visualmente, com base na coloração do fruto. No segundo, avaliou-se o efeito de dois estádios de maturação do fruto e duas temperaturas $\left(25\right.$ e $\left.35^{\circ} \mathrm{C}\right)$ sobre o vigor e germinação das sementes. No terceiro, foi investigada a incidência de fungos nas sementes em duas temperaturas $\left(25\right.$ e $\left.35^{\circ} \mathrm{C}\right)$. Os diferentes níveis de maturação fisiológica avaliados não interferem na porcentagem de sementes germinadas, contundo, influenciam o seu vigor. A temperatura de $25^{\circ} \mathrm{C}$ é adequada para a germinação das sementes de Eugenia involucrata DC. Os gêneros de fungos identificados nas sementes foram Trichoderma, Aspergillus, Fusarium, Penicillium, Alternaria e Colletotrichum apresentando variações na incidência de acordo com a temperatura avaliada.

Palavras-chave: Cerejeira-do-Rio-Grande. Eugenia involucrata. Myrtaceae. Frutíferas nativas. Maturação fisiológica.

Data de recebimento: $25 / 03 / 2020$

Data de aprovação: 29/12/2020

DOI: https://doi.org/10.30612/agrarian.v14i52.11283

\section{Introduction}

Brazil stands out as one of the main centers of genetic diversity of wild fruit trees worldwide. Nevertheless, there is a lack technical information for most of these species. Wild fruits belonging to the family Myrtaceae are widely distributed throughout Brazil, constituting a source of germoplasm of enormous value (Lattuada et al., 2010). The Cerejeira-da-mata, Eugenia involucrata DC., belongs to the Myrtaceae family and is a native species of southern Brazil. It can be found from Minas Gerais to Rio Grande do Sul states in forest formations of the Atlantic complex, and in some regions of Paraná state (Donádio et al., 2004). Besides, E. involucrata also occurs in Mato Grosso do Sul, Minas Gerais and Goiás states, and in other countries of South America as Argentina, Uruguay, and Paraguay (Rodrigues \& Carvalho, 2001).

$E$. involucrata is a native honey plant with great ecological importance disseminated by birds and useful in the recovery of degraded areas (Carvalho, 2008; Rodrigues \& Carvalho, 2001), besides its landscape value due to the beauty of its flowers and stems (Lorenzi, 2002). In addition, this species has fruits that can be consumed fresh and processed to make sweets, jams, and liqueurs (Carvalho, 2008). In addition, has potential for pharmaceutical use, due its digestive, antidiarrheal and antirheumatic properties, and antifungal activity (Sardi et al., 2017; Toledo et al., 2020; Vechi et al., 2018). The wood is of good quality and can be used in civil construction, making agricultural tools, as firewood and for charcoal production (Carvalho, 2008). Due to its great economic and ecological importance, studies aimed at improving propagation of this wild fruit assume significant relevance (Avila et al., 2009).

Data regarding the physiological maturation of fruits and germination of seeds are crucial for the propagation of wild fruits, as they prescribe conditions for the collection and processing of seeds at appropriate times (Nogueira et al., 2013), providing for maximum physiological seed quality. Seed quality is also closely related to the presence of some fungal pathogens that may be associated with a decrease in germination rate and lower seedling development (Yorinori, 1982). Temperature is also an important factor that must be considered in the germination of the seeds, as it directly and indirectly influences the germination process (Huang et al., 2018).

Considering the above-mentioned factors, our objective with this work was to evaluate the effect of physiological maturation and temperature on the germination and fungal incidence in Eugenia involucrata DC. seeds.

\section{Material e Methods}

\subsection{Experimental location}

The experiments were conducted in the laboratory of plant biotechnology and propagation of the Federal University of the Southern Frontier - UFFS, Campus Chapecó-SC, using seeds from four individuals of E. involucrata species located in the municipality of Vitorino $\left(26^{\circ} 15^{\prime} 31.9^{\prime \prime} S\right.$ and $\left.52^{\circ} 47^{\prime} 44.0^{\prime \prime} \mathrm{W}\right)$, Paraná, Brazil. 
The fruits were collected and immediately taken to the laboratory for manual removal of the seed. After processing, the seeds were cleaned with sodium hypochlorite $(2.5 \%$ active chlorine $)$ at a concentration of $10 \%$ $(\mathrm{v} / \mathrm{v})$, for 10 minutes. Then, were placed in a sieve, leaving them in running water for three minutes. After that, experiments I e II carried out as follows:

\subsection{Experiment I - Evaluation of the effects of physiological maturation of fruits on seed germination}

Seeds were removed from fruits at four levels of physiological maturation, determined according to the coloring of the epicarp of the fruit: yellow with red spots (RS), bright red (BR), wine-colored (WC) and fruits that were on the ground (GR). The fruit coloration levels were determined based on the classification of Oro et al. (2012).

The seeds ( 25 seeds per box) were packed in transparent polyethylene boxes with dimensions of $11 \mathrm{x}$ $11 \times 3.5 \mathrm{~cm}$ (Gerbox®) containing a distilled water moistened substrate. The substrate was moistened whenever necessary. The substrate used was of vegetable origin for germination of tree species (Turfa Fértil[; conductivity: $1.5 \pm 0.3 \mathrm{mS} / \mathrm{cm}$; dry weight density: $280 \mathrm{~kg} / \mathrm{m}^{3} ; \mathrm{pH}: 5.5 \pm 05$; water retention capacity: $57 \%$ ). The plastic boxes were placed in bio-oxygen demand incubators with 12-hour light cycles at $25^{\circ} \mathrm{C}$, to evaluate the seed germination parameters.

Emerging seedling counts were performed daily. Seedlings were considered emerged when they presented aerial parts and root systems with sufficient size for determination of normal seedlings, according to the rules for seed analysis (Brazil, 2009). The 'normal seedlings' were growing in tubes to confirm their normal development.

The germination was displayed in percentage of germinated seeds (\%). The mean germination time and the germination speed index (GSI) were calculated according to the method established by Edmond and Drapala (1958) and Maguire (1962), respectively. The first count was performed on the $18^{\text {th }}$ day after installing the experiment.

\subsection{Experimental design and statistical analysis}

The experimental design was completely randomized, with four treatments (different levels of physiological maturation: GR, WC, BR e RS) and five replicates of 25 seeds each. For the variable percentage of germination, the arcsine transformation $(x / 100)^{0.5}$ was used and for the other variables the applied transformation was $(x+1)^{0.5}$. The data was submitted to Liliefors' normality test and analysis of variance ( $F$ test). When a significant difference was observed between the treatments the means were compared by Tukey's test $(p \leq 0,05)$. Sisvar version 5.6 (Ferreira, 2011) and SigmaPlot version 12.5 from Systat Software, Inc., San Jose California USA, were used for statistical analysis.

\subsection{Experiment II - Influence of physiological fruit maturation and temperature on seed germination}

The seeds used were removed from fruits with wine-colored epicarp (WC) and fruits that were on the ground (GR), according to the classification described previously (Experiment I). The seeds were cleaned and sowed in transparent polyethylene boxes with substrate, in the same conditions described in the experiment I, and placed in bio-oxygen demand incubators with 12-hour light cycles at 25 and $35^{\circ} \mathrm{C}$. The parameters evaluated were seed germination (\%), the mean germination time (Edmond \& Drapala, 1958), the germination speed index (Maguire, 1962) and the germination on first count (\%). All the evaluations were carried out as described in the experiment $\mathrm{I}$.

\subsection{Experimental design and statistical analysis}

The experimental design was completely randomized in $2 \times 2$ factorial arrangement with two levels of physiological maturation (WC and GR) and two temperatures $\left(25^{\circ} \mathrm{C}\right.$ and $35^{\circ} \mathrm{C}$ ), with 5 replicates of 25 seeds each. For the variable percentage of germination, the arcsine transformation $(x / 100)^{0.5}$ was used and for the other variables the applied transformation was $(x+1)^{0.5}$. The data was submitted to Liliefors' normality test and analysis of variance $(F$ test). When a significant difference was observed between the treatments the means were compared by Tukey's test $(p \leq 0,05)$. Sisvar version 5.6 (Ferreira, 2011) and SigmaPlot version 12.5 from Systat Software, Inc., San Jose California USA, were used for statistical analysis. 


\subsection{Experiment III - Evaluation of the influence of temperature on the incidence of fungi in seeds}

To evaluate the incidence of fungi in seeds of $E$. involucrata, the seeds were subjected to superficial cleaning with $70 \%$ ethanol $(30 \mathrm{sec}$ ), followed by $1 \%$ sodium hypochlorite $(1 \mathrm{~min})$ and three washes with distilled water (1 min each). Subsequently, the seeds were placed to dry on sterile filter paper at room temperature.

The seeds were packed in plastic transparent boxes (Gerbox®) with distilled water moistened germination paper (Germitest $\Theta$ ) and incubated in bio-oxygen demand incubators at $25^{\circ} \mathrm{C}$ and $35^{\circ} \mathrm{C}$, with a 12-hour light cycle for 7 days. In each box were placed 25 seeds, and the germination paper was moistened with distilled water daily. The method was the "Blotter test" with freezing (Brazil, 2009). To evaluate the incidence of fungi in the seeds, we used stereoscopic and optical microscopes. The fungi present in the samples were identified at the genus level, based on a specialized bibliography (Barnett \& Hunter, 1998), determining the percentage of incidence of each fungal genus.

\subsection{Experimental design and statistical analysis}

The experimental design was completely randomized with 6 replicates of 25 seeds for each evaluated temperature $\left(25^{\circ} \mathrm{C}\right.$ and $\left.35^{\circ} \mathrm{C}\right)$. The data was submitted to the arcsine transformation $(x / 100)^{0.5}$, and then to Liliefors' normality test. The fungal incidence was compared between temperatures for each genus by Student's t-test $(p \leq 0,05)$. SigmaPlot version 12.5 from Systat Software, Inc., San Jose California USA, was used for statistical analysis.

\section{Results and discussion}

\subsection{Experiment I}

Seed germination (SG) was not influenced by the levels of physiological maturation of the fruits, with a mean of $89.25 \%$ of germinated seeds. However, the mean germination time (MGT), germination speed index (GSI) and germination at the first count (FCG) were influenced by the levels of physiological maturation of the fruits (Table 1).

Because seed germination was not influenced, we may infer that the complete formation of the seeds had already occurred at the maturation levels of the fruits evaluated in this study and that, therefore, only the vigor of the seedlings was altered. It is important to point out that the seeds collected from fruits on the ground were visually selected for the presence of insect or fungal damages, being discarded approximately $10 \%$ to $12 \%$ of the total number of seeds collected.

Table 1. Seed germination (SG), mean germination time (MGT), germination speed index (GSI) and first count germination (FCG) of Eugenia involucrata DC. seeds from fruits at different levels of physiological maturation in 12-hour light cycles at $25^{\circ} \mathrm{C}$.

\begin{tabular}{ccccc}
\hline Levels of maturation $^{\#}$ & SG $(\%)$ & MGT (Days) & GSI & FCG (\%) \\
\hline GR & $89.5^{\text {ns }}$ & $23 \mathrm{~b}^{*}$ & $1.01 \mathrm{a}^{*}$ & $20.8 \mathrm{a}^{*}$ \\
WC & 87.0 & $26 \mathrm{a}$ & $0.80 \mathrm{~b}$ & $4.8 \mathrm{c}$ \\
BR & 91.0 & $25 \mathrm{ab}$ & $0.98 \mathrm{a}$ & $12.0 \mathrm{bc}$ \\
RS & 90.0 & $23 \mathrm{~b}$ & $1.06 \mathrm{a}$ & $19.2 \mathrm{ab}$ \\
\hline CV $(\%)$ & 3.41 & 5.25 & 5.21 & 28.52 \\
\hline
\end{tabular}

"Yellow with red spots (RS), bright red (BR), wine-colored (WC) and fruits that were on the ground (GR). ns: not significant. * Means followed by the same letter in the column do not differ significantly by Tukey's test $(p \leq 0.05)$.

The effect of fruit physiological maturation on the germination of $E$. involucrata seeds was verified by Oro et al. (2012). The authors demonstrated that seeds removed from fruits on the ground presented the lowest percentage of germination, while seeds removed from wine-colored fruits exhibited the highest percentage of germination. This difference in seed germination in relation to our study may be related to the visual separation of damaged seeds from the fruits that were on the ground.

The mean seed germination time was highest for seeds from wine-colored fruits (26 days). The seeds from the fruits that were on the ground and fruits with a yellow coloration with red spots exhibited the shortest 
germination time (23 days). Seeds collected from fruits with bright red coloration showed intermediate germination time (25 days). The mechanism of endogenous plant hormonal regulation is supposed to be highly conserved in seed germination process. Genetic and physiological studies have shown the important roles of the phytohormones, abscisic acid (ABA), gibberellins (GAs), ethylene and brassinosteroids in seed germination process (Koornneef et al., 2002; Kucera et al., 2005; Xia et al., 2019). Therefore, the differences in mean germination time of the seeds may be attributed to the presence of substances that negatively modulate the germination process when the fruits reach maturation (wine-colored fruits). On the other hand, in the seeds from fruits that were in the ground these substances were possibly already in lower concentrations, and in the seeds from fruits visually at the beginning of maturation (yellow with red spots), there were still no substances formed or accumulated enough to interfere on the germination process.

Evaluating the mean germination time at various levels of physiological maturation of $E$. involucrata seeds, Oro et al. (2012), showed that seeds of fruits with green coloration (a maturation level not evaluated in the present study) exhibited the highest mean germination time (32 days), while the seeds removed from fruits with bright red color had the shortest mean germination time (27 days). In our study the seeds removed from fruits with bright red color did not present differences compared with seeds removed from fruits yellow with red spots, wine-colored fruits or fruits collected on the ground. The effect of various levels of physiological maturation of the fruits on the mean germination time of the seeds was also demonstrated by Gonçalves et al. (2015), in pepper seeds (Capsicum chinense Jacq.) removed from fruits at five levels of physiological maturation. In that study, seeds from fruits with green color showed the highest mean germination time, and seeds removed from fruits with red-carmine color (the most advanced maturation level) had the shortest mean germination time.

We observed the shortest germination speed index in seeds removed from wine-colored fruits, being $21.56 \%$ lower than the other maturation levels evaluated. Seeds removed from fruits that were on the ground, bright red fruits and yellow fruits with red spots exhibited the highest germination speed index, with a mean of 1.02, not different from one another. Evaluating the effect of physiological maturation on the germination of Luehea divaricate, Schulz et al. (2017), observed that the germination speed index was highest in seeds obtained from fruits with green coloration than that of brown fruits. Brown-colored fruits corresponded to a stage of maturation more advanced than the that of fruits with green coloration. However, when the fruit reached the most advanced level of maturation evaluated, the germination speed index did not differ from that of other stages of maturation. In the present study, seeds removed from fruits collected on the ground showed the highest percentage of seeds germinated at the first count, with an increase of $8.8 \%$ and $16 \%$ compared to seeds from bright red and wine-colored fruits, respectively. However, seeds from fruits collected on the ground did not differ of the seeds from yellow-colored fruits and red spots, with a mean of $20 \%$ of germinated seeds at the first count.

Seed germination began on the $18^{\text {th }}$ day and extended until the $58^{\text {th }}$ day after the experiment implementation. The seeds from wine-colored fruits had the lowest germination percentages per unit of time (Figure 1). The same behavior was also observed for the germination speed index, mean germination time and percentage of seeds germinated at first count shown previously (Table 1). These results indicating curiously that the seeds show a reduction of vigor at this moment for some reason yet don't know in this species.

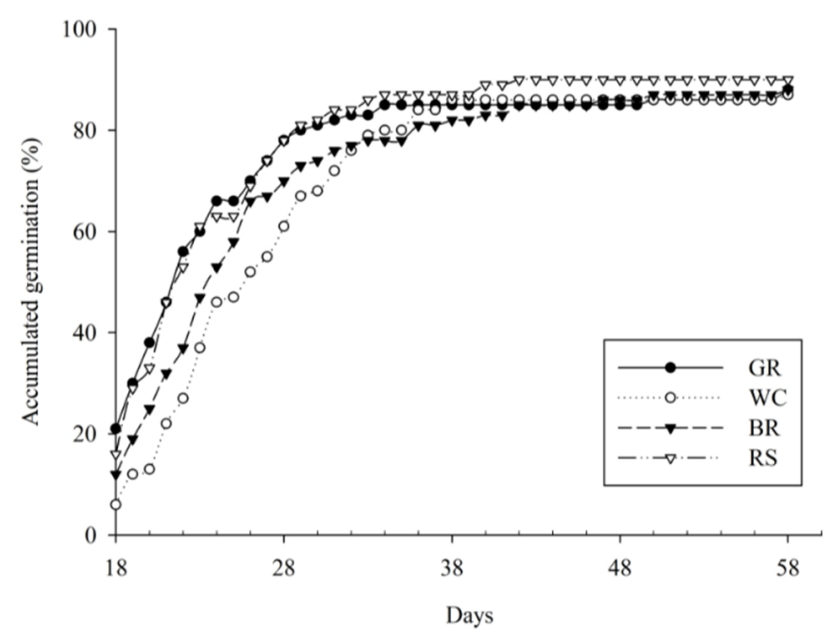


Figure 1. Accumulted germination of Eugenia involucrata DC. seeds. Seeds removed from fruits yellow with red spots (RS), bright red (BR), wine-colored (WC), and fruits that were on the ground (GR).

Seed germination can occur normally even when they are not physiologically 'ready'. However, when this happens, there is the possibility of delayed seed germination and the formation of seedlings with low vigor (Carvalho \& Nakagawa, 2012). This phenomenon was observed in our study, where only the vigor of the seedlings was influenced by the levels of physiological maturation of the fruit evaluated. The germinative process and initial seedling development, in addition to being influenced by environmental conditions, is controlled by the interaction of endogenous phytohormones, such as gibberellic acid (germination promoter) and abscisic acid (germination inhibitor). Recently, it was demonstrated that auxins acting negatively on germination. The phytohormones ethylene and brassinosteroids also influence the germination process (Finkelstein et al., 2008; Gupta \& Chakrabarty, 2013; Koornneef et al., 2002; Kucera et al., 2005; Shu et al., 2016; Xia et al., 2019). Thus, it can be inferred that the variation of the germinative parameters related to the vigor of the seeds demonstrated in our study for the different levels of fruit maturation evaluated, may be related to fluctuations and/or interactions among phytohormones on germinative process.

The plant's environmental conditions at the time of seed formation can also influence the germination of the seeds, as demonstrated by Huang et al. (2018). Considering this fact, it may be inferred yet that some discrepancies in the results obtained in our study from those of other studies may be related to local and temporal variations in climatic conditions at the time of seed formation. In addition, one may mention the peculiarities of each species with respect to environmental and physiological conditions that modulate the germinative process.

\subsection{Experiment II}

The mean germination time (TMG), the germination speed index (GSI), and the percentage of seed germination in the first count (FCG) were influenced by temperature and physiological levels of fruit maturation. There was an interaction between temperature and physiological maturation levels of the fruit for the vigor of the seeds. However, seed germination (SG) was influenced only by temperature (Table 2).

Table 2. Seed germination (SG), mean germination time (MGT), germination speed index (GSI) and first count germination (FCG) of Eugenia involucrata DC. seeds from wine-colored fruits and fruits that were on the ground in two temperatures $\left(25^{\circ} \mathrm{C}\right.$ and $\left.35^{\circ} \mathrm{C}\right)$ with 12-hour light cycles.

\begin{tabular}{|c|c|c|}
\hline \multirow{2}{*}{ Temperature } & \multicolumn{2}{|c|}{ Levels of physiological maturation } \\
\hline & GR & WC \\
\hline \multicolumn{3}{|c|}{ Seed germination (\%) } \\
\hline $25^{\circ} \mathrm{C}$ & $89.5 \mathrm{aA}^{*}$ & $87.0 \mathrm{aA}$ \\
\hline $35^{\circ} \mathrm{C}$ & $0.00 \mathrm{bA}$ & $0.00 \mathrm{bA}$ \\
\hline $\mathrm{CV}(\%)$ & & \\
\hline \multicolumn{3}{|c|}{$\frac{2.60}{\text { Mean germination time (Days) }}$} \\
\hline $25^{\circ} \mathrm{C}$ & $23.5 \mathrm{aA}^{7}$ & $26.0 \mathrm{aB}$ \\
\hline $35^{\circ} \mathrm{C}$ & $0.00 \mathrm{bA}$ & $0.00 \mathrm{bA}$ \\
\hline $\mathrm{CV}(\%)$ & \multicolumn{2}{|c|}{5.34} \\
\hline \multicolumn{3}{|c|}{ Germination speed index (GSI) } \\
\hline $25^{\circ} \mathrm{C}$ & $1.01 \mathrm{aA}^{7}$ & $0.80 \mathrm{aB}$ \\
\hline $35^{\circ} \mathrm{C}$ & $0.00 \mathrm{bA}$ & $0.00 \mathrm{bA}$ \\
\hline CV $(\%)$ & \multicolumn{2}{|c|}{3.02} \\
\hline \multicolumn{3}{|c|}{ First count germination (\%) } \\
\hline $25^{\circ} \mathrm{C}$ & $21.8 \mathrm{aA}^{¥}$ & $5.8 \mathrm{aB}$ \\
\hline $35^{\circ} \mathrm{C}$ & $0.00 \mathrm{bA}$ & $0.00 \mathrm{bA}$ \\
\hline CV $(\%)$ & \multicolumn{2}{|c|}{48.41} \\
\hline
\end{tabular}


Seed dormancy is common in wild plants and ensures that seeds germinate only when environmental conditions are optimal. It thus is an adaptive trait in numerous seed-plant species, enabling wild plants to survive under stressful conditions in nature (Finkelstein et al., 2008; Shu et al., 2016). Temperature is among the principal factors influencing seed germination (Pereira et al., 2013), being able to alter the rate of water absorption and the biochemical reactions that determine the germination process (Carvalho \& Nakagawa, 2012). In this study, the influence of temperature on the germination of $E$. involucrata seeds was clearly seen, because when they were exposed to a temperature of $35{ }^{\circ} \mathrm{C}$ there was total inhibition of germination (e.g.; secondary dormancy) at both fruit maturation levels evaluated.

Results demonstrating the negative influence of high temperatures on seed germination and emergence of seedlings were reported by Oliveira and Barbosa (2014) in their work with Cedrela fissilis. The authors demonstrated that germination was impaired with increasing temperature and that the lower germination percentage was observed when the seeds were exposed to $35^{\circ} \mathrm{C}$. The influence of temperature on seed germination was also verified by Gomes et al. (2016) in their study with Eugenia involucrata, Campomanesia xanthocarpa, Acca sellowiana and Eugenia pyriformis. The results obtained by these authors corroborate with those found in our study, demonstrating that $E$. involucrata seeds exhibited the highest seed germination at $25{ }^{\circ} \mathrm{C}$. However, Lamarca et al. (2011) did not verify differences in seed germination of $E$. involucrata among the temperatures of 20,25 and $30^{\circ} \mathrm{C}$, and the alternate temperatures of $20 / 30$ and $20 / 35$ ${ }^{\circ} \mathrm{C}$.

The mean germination time at $25^{\circ} \mathrm{C}$ was lower for seeds collected from fruits that were on the ground (Table 2), as demonstrated in experiment I, showing a reduction of 2.5 days in relation of the seeds removed from wine-colored fruits. The influence of temperature on mean germination time was also demonstrated in other studies. Nogueira et al. (2014), evaluating the effect of temperature and the presence or absence of light on the Dalbergia cearensis seeds, showed that the lowest germination time of the seeds occurred between $25^{\circ} \mathrm{C}$ and $30^{\circ} \mathrm{C}$.

The germination speed index at $25{ }^{\circ} \mathrm{C}$ obtained in our study was highest for fruits collected on the ground, with an increase of $20.8 \%$ when compared with seeds removed from wine-colored fruits. Lamarca et al. (2011) observed similar results, with the highest germination speed index of $E$. involucrata seeds at 25 and $30{ }^{\circ} \mathrm{C}$. Significant differences were also observed by Nogueira et al. (2014), evaluating the effect of temperature and the presence and absence of light on the seeds of Dalbergia cearensis, where the highest germination speed index was detected at temperatures of $25^{\circ} \mathrm{C}$ and $30^{\circ} \mathrm{C}$. On the other hand, Zucareli et al. (2015), evaluating the effect of temperature and light on the germination of Passiflora incarnata seeds, demonstrated that the highest values of germination speed index were obtained at $35{ }^{\circ} \mathrm{C}$. These results indicating that different species exhibited distinctions with respect to the best temperature for seed germination, a factor that may be associated with the environmental conditions and physiological adaptation of each species.

The percentage of germination at the first count was $20 \%$ highest at $25{ }^{\circ} \mathrm{C}$ in seeds from fruits collected on the ground. Melo et al. (2017), evaluating the effect of different substrates and temperatures on the germination of Eriotheca gracilipes seeds, also demonstrated the influence of temperature on seed germination in all tested substrates. The authors demonstrated that the highest germination at first count occurred at 25 and $30^{\circ} \mathrm{C}$ for E. gracilipes.

Seed germination can be influenced by external and internal factors. Internal factors include physiological dormancy and seed viability, among others. External factors include availability of water (in the seed and the substrate of germination), luminosity, the presence of gases (particularly $\mathrm{O}_{2}$ ) and temperature (Carvalho \& Nakagawa, 2012). In this study, it was possible to clearly demonstrate the effect of temperature on the germination of $E$. involucrata seeds. The effect triggered on $E$. involucrata seeds at $35^{\circ} \mathrm{C}$ can be characterized as termo-dormancy, that is, inhibition of seed germination due to temperature. According to Huang et al. (2018), dormancy is dependent on the temperature at the time of seed formation in the plant ('maternal temperature'). Therefore, because $E$. involucrata is a native species of mild temperatures, it can be inferred that $35^{\circ} \mathrm{C}$ prevented the germination of seeds of this species by creating an environment different from the favorable conditions for its development, like a survival strategy in stressful conditions.

\subsection{Experiment III}

Seed germination and the initial development of the seedlings are related to seed health. Some fungal pathogens can affect negatively seeds depending on environmental conditions. The primary factors for fungal 
development in seeds are temperature and humidity. Therefore, in our study, we evaluated the incidence of the fungi in $E$. involucrata seeds at 25 and $35^{\circ} \mathrm{C}$.

The seed health test revealed the presence of six fungi genus in the $E$. involucrata seeds and the influence of temperature on their development (Figure 2). The following fungi genera were identified: Trichoderma, Fusarium, Penicillium, Colletotrichum, Aspergillus, and Alternaria. The fungi genera Penicillium, Aspergillus and Colletotrichum exhibited the highest incidence at $25^{\circ} \mathrm{C}$ while, Alternaria was the unique fungi genus that exhibited the highest incidence at $35^{\circ} \mathrm{C}$. The fungi genus Trichoderma showed non-temperaturedependence for its development in the $E$. involucrata seeds.

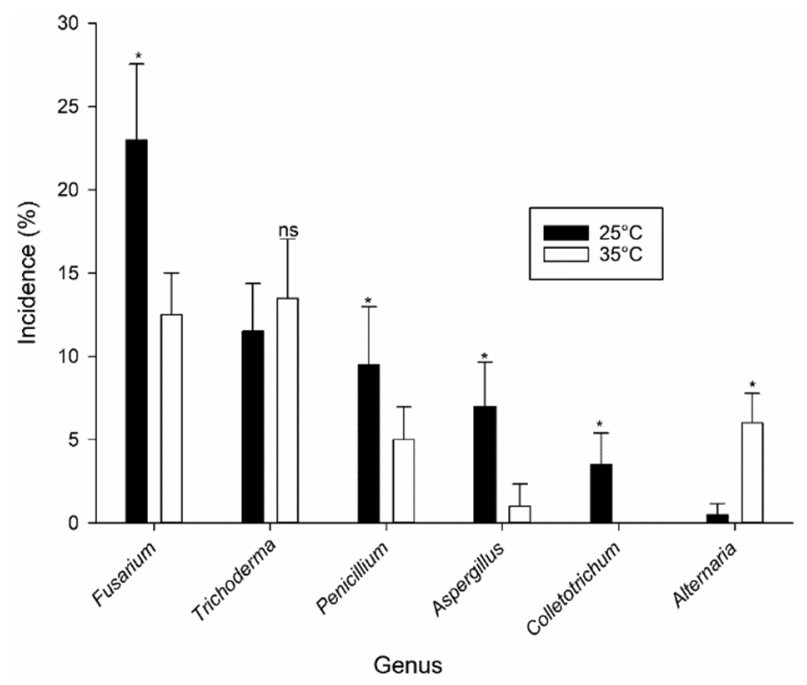

Figure 2. Incidence of fungi by genus (\%) in Eugenia involucrata DC. seeds at 25 and $35^{\circ} \mathrm{C}$ with 12 -hour light cycles. ${ }^{*}$ Indicates significant differences in the fungi growing under the two temperatures by Student's t-test $(p \leq 0.05)$. ns: not significant.

At $25{ }^{\circ} \mathrm{C}$, the fungi genera Fusarium, Trichoderma, Penicillium, Aspergillus, Colletotrichum, and Alternaria were detected in $23 \%, 11.5 \%, 9.5 \%, 7 \%, 3.5 \%$, and $1 \%$ of the seeds, respectively. At $35{ }^{\circ} \mathrm{C}$, the fungi genera Trichoderma, Fusarium, Alternaria, Penicillium, Aspergillus were detected in 13.5\%, 12.5\%, 6\%, $5 \%$ and $1 \%$ of the seeds, respectively. The fungi genus Colletotrichum did not develop at $35^{\circ} \mathrm{C}$.

Oliveira et al. (2011) evaluated the influence of various thermal treatments on fungi control in Eugenia brasiliensis, Eugenia pyriformis and Eugenia uniflora seeds, and observed the effect of temperature on the incidence of fungi in seeds. Various water temperatures were used, and various periods of time in which the seeds remained under these conditions. The authors demonstrated that the treatments tested modified the development of fungi genera Cladosporium, Penicillium, Pestalotiopsis, and Alternaria present in the seeds.

\section{Conclusion}

Considering the conditions under which our study was carried out, it is possible to point out:

The temperature of $25^{\circ} \mathrm{C}$ is adequate for $E$. involucrata seed germination. The different levels of maturation evaluated do not affect the percentage of germinated seeds, however, influence their vigor. Seeds removed from yellow fruits with red spots and from fruits collected on the ground exhibited good germination and faster seedling development and may be used to the propagation of E. involucrata. Nevertheless, it is important to mention that the seeds removed from fruits collected on the ground should be inspected visually at the time of processing, so that it is possible to remove damaged seeds.

The influence of temperature on the fungi development in the seeds of $E$. involucrata can be clearly observed. However, the effective temperature for decreasing the fungi development inhibited the germination of the seeds, making it impossible to use this method as an auxiliary technique to control the health of the seeds. In addition, further studies should be carried out to identify which fungi genus are harmful and which ones are beneficial or neutral to the seed germination. The effect of the temperatures lower than $35^{\circ} \mathrm{C}$, where the seeds germinate and hinder the harmful fungi development may be investigated.

\section{References}


Avila, A.L., Argenta, M.D.S., Muniz, M.F.B., Poleto, I., \& Blume, E. (2009). Maturação fisiológica e coleta de sementes de Eugenia uniflora L. (Pitanga), Santa Maria, RS. Ciência Florestal, 19(1), 61-68. https://doi.org/10.5902/19805098420

Barnett, H.L. \& Hunter, B.B. (1998). Illustrated genera of imperfect fungi (4th ed). APS Press.

Brazil, Ministry of Agriculture of Livestock, and Food Supply (MAPA). (2009). Regras para análise de sementes. Secretaria de Defesa Agropecuária. Brasília: Mapa/ACS.

Carvalho, P.E.R. (2008). Espécies arbóreas brasileiras (Vol. 3). Embrapa Informação Tecnológica.

Carvalho, P.E.R. \& Nakagawa, J. (2012). Sementes: Ciência, tecnologia e produção (Vol. 3). FUNEP.

Donádio, L.C., Môro, F.V. \& Servidone, A.A. (2004). Frutas brasileiras (2a). Novos Talentos.

Edmond, J.B. \& Drapala, W.J. (1958). The effects of temperature, sand, soil, and acetone on germination of okra seeds. Proceedings of the American Society for Horticultural Science, 71, 428-434.

Ferreira, D.F. (2011). Sisvar: A computer statistical analysis system. Ciência e Agrotecnologia, 35, 10391042.

Finkelstein, R., Reeves, W., Ariizumi, T. \& Steber, C. (2008). Molecular Aspects of Seed Dormancy. Annual Review of Plant Biology, 59(1), 387-415. https://doi.org/10.1146/annurev.arplant.59.032607.092740

Gomes, J.P., Oliveira, L.M., Ferreira, P.I. \& Batista, F. (2016). Substratos e temperaturas para teste de germinação em sementes de Myrtaceae. Ciência Florestal, 26(1), $285-293$. https://doi.org/10.5902/1980509821120

Gonçalves, V.D., Müller, D.H., Fava, C.L.F. \& Camili, E.C. (2015). Maturação fisiológica de sementes de pimenta "Bode vermelha". Revista Caatinga, 28(3), 137-146. https://doi.org/10.1590/198321252015v28n316rc

Gupta, R. \& Chakrabarty, S.K. (2013). Gibberellic acid in plant: Still a mystery unresolved. Plant Signaling \& Behavior, 8(9), e25504. https://doi.org/10.4161/psb.25504

Huang, Z., Footitt, S., Tang, A. \& Finch-Savage, W.E. (2018). Predicted global warming scenarios impact on the mother plant to alter seed dormancy and germination behaviour in Arabidopsis. Plant, Cell \& Environment, 41(1), 187-197. https://doi.org/10.1111/pce.13082

Koornneef, M., Bentsink, L. \& Hilhorst, H. (2002). Seed dormancy and germination. Current Opinion in Plant Biology, 5(1), 33-36. https://doi.org/10.1016/S1369-5266(01)00219-9

Kucera, B., Cohn, M.A. \& Leubner-Metzger, G. (2005). Plant hormone interactions during seed dormancy release and germination. Seed Science Research, 15(4), 281-307. https://doi.org/10.1079/SSR2005218

Lamarca, E.V., Silva, C.V. \& Barbedo, C. J. (2011). Limites térmicos para a germinação em função da origem de sementes de espécies de Eugenia (Myrtaceae) nativas do Brasil. Acta Botanica Brasilica, 25(2), 293-300. https://doi.org/10.1590/S0102-33062011000200005

Lattuada, D.S., Souza, P.V.D. \& Gonzatto, M.P. (2010). Enxertia herbácea em Myrtaceae nativas do Rio Grande do Sul. Revista Brasileira de Fruticultura, 32(4), 1285-1288. https://doi.org/10.1590/S010029452010005000115

Lorenzi, H. (2002). Árvores brasileiras: Manual de identificação e cultivo de plantas arbóreas nativas do Brasil (5a. ed, Vol. 2). Instituto Plantarum de Estudos da Flora.

Maguire, J.D. (1962). Speed of germination-aid in selection and evaluation for seedling emergence and vigor. Crop Science, 2(2), 176-177. https://doi.org/10.2135/cropsci1962.0011183X000200020033x

Melo, P.A.F.R., Cavalcanti, M.I.P., Alves,E.U., Martins, C.C. \& Araújo, L.R. (2017). Substrates and temperatures in the germination of Eriotheca gracilipes seeds. Revista Ciência Agronômica, 48(2), 303-309.

Nogueira, F.C.B., Gallão, M.I., Bezerra, A.M.E. \& Medeiros Filho, S. (2014). Efeito da temperatura e luz na germinação de sementes de Dalbergia cearensis Ducke. Ciência Florestal, 24(4), 995-1005. https://doi.org/10.5902/1980509816613 
Nogueira, N.W., Ribeiro, M.C.C., Freitas, R.M., Martins, H.V.G. \& Leal, C.C. (2013). Maturação fisiológica e dormência em sementes de Sabiá ( Mimosa caesalpiniifolia BENTH.). Bioscience Journal, 29, 876-883.

Oliveira, A.K.M. \& Barbosa, L.A. (2014). Efeitos da temperatura na germinação de sementes e na formação de plântulas de Cedrela fissilis. FLORESTA, 44(3), 441. https://doi.org/10.5380/rf.v44i3.33260

Oliveira, C.F., Oliveira, D.C., Parisi, J.J.D. \& Barbedo, C.J. (2011). Deterioração de sementes de espécies brasileiras de Eugenia em função da incidência e do controle de fungos. Revista Brasileira de Sementes, 33(3), 520-532. https://doi.org/10.1590/S0101-31222011000300015

Oro, P. (2012). Maturação fisiológica de sementes de Eugenia pyriformis Cambess e Eugenia involucrata DC. Biotemas, 25(3), 11-18. https://doi.org/10.5007/2175-7925.2012v25n3p11

Pereira, S.R., KALIFE, C., RODRIGUES, A.P.D.C. \& LAURA, V.A. (2013). Influência da temperatura na germinação de sementes de Peltophorum dubium (Spreng.) Taub. Informativo ABRATES, 23, 52-55.

Rodrigues, V.E.G. \& Carvalho, D.A. (2001). Levantamento etnobotânico de plantas medicinais no domínio do cerrado na região do alto rio grande-Minas Gerais. Ciência e Agrotecnologia, 25, 102-123.

Sardi, J.C.O., Freires, I.A., Lazarini, J.G., Infante, J., Alencar, S.M. \& Rosalen, P.L. (2017). Unexplored endemic fruit species from Brazil: Antibiofilm properties, insights into mode of action, and systemic toxicity of four Eugenia spp. Microbial Pathogenesis, 105, 280-287. https://doi.org/10.1016/j.micpath.2017.02.044

Schulz, D.G., Schneider, C.F., Gusatto, F.C., Ignácio, V.L., Malavasi, M.D.M. \& Malavasi, U.C. (2017). Physiological and enzymatic changes during seed maturation and germination of Luehea divaricata. FLORESTA, 47(1), 105. https://doi.org/10.5380/rf.v47i1.44203

Shu, K., Liu, X., Xie, Q. \& He, Z. (2016). Two faces of one seed: hormonal regulation of dormancy and germination. Molecular Plant, 9(1), 34-45. https://doi.org/10.1016/j.molp.2015.08.010

Toledo, A.G., Souza, J.G.L., Silva, J.P.B., Favreto, W.A.J., Costa, W.F. \& Pinto, F.G.S. (2020). Chemical composition, antimicrobial and antioxidant activity of the essential oil of leaves of Eugenia involucrata DC. Bioscience Journal, 36(2). https://doi.org/10.14393/BJ-v36n2a2020-48096

Vechi, G., Campos, A., Rosa, R.L., Capistrano, K., Zermiani, T., Buzzi, S.F.A. \& Filho, V.C. (2018). Analyses of chemical composition and gastroprotective and antinociceptive properties of Eugenia involucrata DC. leaves. Journal of Applied Pharmaceutical Science, 79-83. https://doi.org/10.7324/JAPS.2018.8411

Xia, Q., Ponnaiah, M., Thanikathansubramanian, K., Corbineau, F., Bailly, C., Nambara, E., Meimoun, P. \& ElMaarouf-Bouteau, H. (2019). Re-localization of hormone effectors is associated with dormancy alleviation by temperature and after-ripening in sunflower seeds. Scientific Reports, 9(1), 4861. https://doi.org/10.1038/s41598-019-40494-w

Yorinori, J.T. (1982). Doenças da soja causadas por fungos. Informe Agropecuário, 8(2), 40-46.

Zucareli, V., Henrique, L.A. \& Ono, E.O. (2015). Influence of light and temperature on the germination of Passiflora incarnata L. seeds. Journal of Seed Science, 37(2), 162-167. https://doi.org/10.1590/2317$1545 v 37 n 2147082$ 